\title{
Indeks Ketahanan Lingkungan sebagai Bukti Pembuatan Kebijakan: Sebuah Sosialisasi Evidence-based Policy di Desa Lorok, Kecamatan Indralaya Utara, Kabupaten Ogan Ilir
}

\author{
Environmental Resilience Index as Evidence of Policy Making: An Evidence-based Policy \\ Outreach in Lorok Village, North Indralaya District, Ogan Ilir Regency
}

Faisal Nomaini
Muhammad Husni Thamrin
Oemar Madri Bafadhal*
Department of Communication
Sciences, Universitas Sriwijaya, Ogan
Ilir Regency, South Sumatera,
Indonesia
email:
madribafadhal@fisip.unsri.ac.id
Kata Kunci
Desa
Evidence-based policy
Indeks desa membangun
Indeks ketahanan lingkungan
Keywords:
Village
Evidence-based policy
Village developing index
Environmental resilience index
Accepted: May 2021
Published: June 2021

\begin{abstract}
Abstrak
Para praktisi dan akademisi dihadapkan pada kebingungan tentang mengapa kebijakan publik gagal mencapai tujuannya dan mendapatkan resistensi dari masyarakat. Hal ini kemudian mendorong lahirnya konsep kebijakan berbasis bukti (evidence-based policy) yang dipercaya dan telah terbukti mampu meningkatkan keberhasilan kebijakan. Sayangnya, konsep ini belum menyentuh pada level pemerintah desa dan oleh karena itu, pengabdian kepada masyarakat ini bertujuan untuk mensosialisasikan konsep tersebut dan mempraktikkannya dengan mengambil studi kasus pada indeks ketahanan lingkungan sebagai salah satu penyususn indeks desa membangun (IDM). Kami mengambil studi kasusu di Desa Lorok, Kecamatan Indralaya Utara, Kabuupaten Ogan Ilir karena beberapa alasan seperti tata kelola pemerintahan dan kesiapan mereka dalam menerima konsep baru ini. Hasil dari pengabdian masyarakat ini adalah berupa model pelaksanaan EBP yang sesuai dengan kebutuhan dan karakteristik masyarakat karena ia dirumuskan bersama-sama antara kami sebagai akademisi dan masyarakat. Hasil lainnya adalah rekomendasi kebijakan untuk peningkatan ketahanan lingkungan dengan berfokus pada kriteria penyusun indeks.
\end{abstract}

\begin{abstract}
Practitioners and academics are faced with problems about why public policy fails to achieve its goals and is met with resistance from the public. This then led to the birth of an evidence-based policy (EBP) concept that is trusted and has been proven to increase policy success. Unfortunately, this concept has not yet reached the village government level. Therefore, this community service aims to socialize this concept and put it into practice by taking a case study on the environmental resilience index as one of the compilations of the village developing index (IDM). We took a case study in Desa Lorok, Kecamatan Indralaya Utara, Kabupaten Ogan Ilir for several reasons, such as governance and their readiness to accept this new concept. This community service is a model for implementing EBP by the needs and characteristics of the community because it is formulated jointly between us as academics and the community. Another result is policy recommendations for increasing environmental resilience by focusing on the criteria composing the index.
\end{abstract}

(c) 2021 Faisal Nomaini, Muhammad Husni Thamrin, Oemar Madri Bafadhal. Published by Institute for Research and Community Services Universitas Muhammadiyah Palangkaraya. This is Open Access article under the CCBY-SA License (http://creativecommons.org/licenses/by-sa/4.0/). $\quad$ DOI: https:// doi.org/10.33084/pengabdianmu.v6i4.1849

\section{PENDAHULUAN}

Kebijakan berbasis bukti (Evidence-based Policy, EBP) mendorong pemerintah dan para pengambil kebijakan untuk menggabungkan bukti berupa bukti-bukti obyektif sebagai pertimbangan dalam perumusan kebijakan (Gallego \& Font, 2020; Head, 2008). Evidencebased Policy dengan kata lain adalah suatu kebijakan public yang berlandasarkan bukti-bukti obyektif. Tujuan 
utama dari aktivitas semacam itu adalah untuk meningkatkan reliabilitas dari berbagai pertmbangan untuk meningkatkan efisiensi dan efektivitas kebijakan dan program (Craft \& Howlett, 2012; Pawson, 2002a). Evidence-based Policy juga muncul sebagai upaya untuk mengurangi pengaruh ideologi dan kepentingan politik dalam proses pengambilan kebijakan. Bukti yang dapat diintegrasikan dalam proses pembuatan kebijakan bervariasi dari riset, pengetahuan dan informasi, ide dan kepentingan, pertimbangan politik sampai dengan bukti-bukti ekonomi (Head, 2008).

Secara umum, pemerintah sebenarnya telah menggunakan bukti sebagai bahan pembuatan kebijakan. Sebagai contoh dalam pembuatan RPJMD terdapat berbagai macam data time series yang telah digunakan untuk melihat kinerja pemerintah selama lima tahun terakhir dan oleh karena itu, RPJMD dapat dikatakan sebagai salah satu produk kebijakan berbasis bukti (Febrian \& Handrisal, 2018). Secara lebih detail, berbagai data baik yang sumbernya dari BPS ataupun data yang diproduksi oleh pemerintah sendiri telah mewarnai RPJMD. Sayangnya, dimensi politik dari RPJMD mungkin memainkan peranan yang lebih besar. Ini terlihat dari adanya visi dan misi kepala daerah yang menjadi landasan dalam perumusan strategi, kebijakan dan program (Mustain \& Djaja, 2017).

Tantangan lain adalah bahwa bukti tidak serta merta dapat dijadikan landasan dalam pembuatan kebijakan. Ini selain dari kemauan dari para pembuat kebijakan juga karena sifat bukti ilmiah yang terkadang tidak mudah untuk diterjemahkan ke dalam bahasa kebijakan yang sifatnya teknis (Kusnanto, 2008). Beberapa limitasi dari bukti ilmiah dalam pembuatan kebijakan antara lain kecepatan (penelitian/penyediaan bukti membutuhkan waktu yang tidak singkat), pembalikan (keinginan publik terkadang berkebalikan dengan kebutuhan mereka), kedangkalan (masalah publik yang bervariasi dan dinamis membuat hasil penelitian mungkin saja cepat berubah), kerahasiaan (beberapa bukti bersifat rahasia) dan ketidakpedulian pada bukti ilmiah (acuh tak acuh dari para pemangku kepentingan) (Asmara \& Handoyo, 2015).

Dari kelima kendala tersebut, salah satu kendala yang mendesak untuk segera diselesaikan adalah ketidakpedulian pada bukti ilmiah atau seringkali disebut dengan scientific ignorance. Para politisi, pemerintah dan pembuat kebijakan, untuk mengurangi, hal tersebut harus diberikan pemahaman mengenai pentingnya dan urgensi bukti dalam pembuatan kebijakan. Berlarut-larut dan bertahun-tahun terjebak dalam masalah publik dapat dihindari dengan mengintegrasikan bukti dalam perumusan kebijakan. Dengan adanya kepedulian terhadap bukti ilmiah para pemangku kepentingan, sebenarnya, dapat memperoleh berbagai macam ide-ide yang lebih konkrit terarah dan membumi dan peka terhadap masalah publik.

Berbagai macam tingkatan pemerintah memerlukan pemahaman tetang konsep baru tersebut. Pemerintah pusat telah memulai dengan mengadakan berbagai macam kegiatan dan terdapat kemauan besar untuk memberikan anggaran penelitian baik kepada mitra ataupun lembaga non kementerian seperti LIPI dan BNPT (Syawie \& Sumarno, 2015). Sementara itu, pemerintah daerah telah memiliki agensi penelitian dan pengembangan yang berdiri sendiri ataupun melekat pada agensi perencanaan pembangunan. Sementara itu, level pemerintah yang paling rendah yaitu pemerintahan desa masih asing dengan konsep tersebut dan tentunya menghadapi kendala yang lebih besar dalam menerapkan konsep semacam ini.

Sementara perhatian pemerintah terhadap desa meningkat yang dilihat dari alokasi anggaran besarbesaran melalui dana desa dan alokasi dana desa, 
ketidaktepatan sasaran kebijakan dan program menjadi masalah yang menanti (Astuti et al., 2020). Ini dikhawatirkan akan menjadi suatu fenomena pemborosan anggaran besar-besaran karena kebijakan dan program yang direncanakan ternyata gagal bertemu dengan masalah-masalah publik di desa (Damayanti \& Syarifuddin, 2020; Purwaningrum \& Short, 2018).

Oleh karena itu para pemangku kepentingan di desa perlu diberikan pemahaman yang komprehensif tentang pentingnya EBP dalam menjembatani masalah publik di desa dan kebiajkan serta program yang tertuang dalam APBDes dan pada akhirnya cita-cita peningkatan kesejahteraan masyarakat desa dapat dengan mudah diraih. Pentingnya hal tersebut mendorong kami untuk mengadakan kegiatan pengabdian masyarakat yang bertujuan untuk memberikan pemahaman kepada para pemangku kepentingan tentang kebijakan berbasis bukti dengan mengambil kasus pada indeks ketahanan lingkungan di Desa Lorok, Kecamatan Indralaya Utara, Kabupaten Ogan Ilir.

\section{METODOLOGI}

Kegiatan ini diawali dengan melakukan survei prakegiatan ke Desa Lorok, Kecamatan Indralaya Utara, Kabupaten Ogan Ilir. Pra-survei ditujukan untuk mendalami persoalan kualitas lingkungan dan EBP di desa ini sekaligus untuk dilakukan untuk menjaring aspirasi masyarakat dan perangkat desa mengenai kebutuhan dan minat mereka untuk mendapatkan penguatan pemahaman yang menyeluruh mengenai topik Indeks Ketahanan Lingkungan dan EBP. Kegiatan ini diawali dengan melakukan survei pra-kegiatan ke Desa Lorok Kecamatan Indralaya Utara Kabupaten Ogan Ilir.

Pelaksanaan kegiatan menggunakan konsep sosialisasi dengan materi utama dari Peraturan Menteri Desa, Pembangunan Daerah Tertinggal, dan Transmigrasi
Republik Indonesia Nomor 2 Tahun 2016 Tentang Indeks Desa Membangun. Secara khusus materi yang dambil dari peraturan ini adalah mengenai Indeks Ketahanan Lingkungan (Ekologi) yang secara jelas telah diuraikan di peraturan ini. Selain itu kami juga secara khusus menggelar focus group discussion untuk menjaring aspirasi masyarakat dan perangkat desa tentang EBP dan Indeks Ketahanan Lingkungan. Sehubungan dengan kondisi Pandemi COVID-19 yang masih melingkupi aspek kehidupan masyarakat maka skema sosialisasi yang dilakukan akan menggunakan protokol kesehatan yang sesuai dengan standar yang diberlakukan secara umum.

\section{HASIL DAN PEMBAHASAN}

Desa Lorok, Kecamatan Indralaya Utara, Kabupaten Ogan Ilir Desa Lorok adalah salah satu desa yang berada di Kecamatan Indralaya Utara, Kabupaten Ogan Ilir, SumatraSelatan, Indonesia. Desa yang berjarak sekitar 41 $\mathrm{km}$ dari pusat Kota Palembang. Desa Lorok terpilih menjadi pemenang Lomba Desa tingkat Provinsi tahun 2013. Desa Lorok Juga memiliki cerita legenda seorang Raden Kuning yang memiliki bukti peningggalan berupa makam yang terletak di desa Lorok ini.

Di Desa ini telah tersedia berbagai macam sarana dan prasarana seperti tempat ibadah dan sarana olahraga, dan sarana kesehatan. Ditinjau dari tata kelola desa, terdapat beberapa permasalahan yang menjadikan pentingnya kegiatan sosialisasi EBP ini. Pertama adalah berkaitan dengan fungsi dari berbagai lembaga yang dibawah naungan Pemerintah Desa seperti Karang Taruna, PKK dan lain sebagainya. Masalah lain adalah minimnya program pemberdayaan masyarakat desa yang sangat dibutuhkan oleh masyarakat. Masalah lain adalah masalah koordinasi dan kapabilitas serta kapasitas desa. Persoalan-persoalan tersebut meskipun telah diintervensi dari berbagai macam program dan 
kebijakan dari pemerintah desa namun tetap muncul setiap tahunnya. Ini mengindikasikan adanya kebutuhan untuk melaksanakan kebijakan yang berbasis bukti untuk menghubungkan masalah publik dengan kebijakan publik (Agustina et al., 2018).

\section{Indeks Ketahanan Lingkungan Desa}

Indeks ketahanan lingkungan desa merupakan bagian dari indek desa membangun (IDM). Indeks Desa membangun berperan sebagai evaluator dalam berbagai aspek untuk menentukan kemajuan dan kualitas suatu desa. Dimensi dari IDM sendiri terdiri dari tiga indeks yaitu Indeks Ketahanan Sosial; Indeks Ketahanan Ekonomi; dan Indeks Ketahanan Lingkungan (Kementerian Desa, Pembangunan Daerah Tertinggal dan Transmigrasi, 2020). Ketiga indeks ini dirumuskan secara detil untuk merumuskan kompleksitas yang ada pada suatu desa ke dalam status kemajuan desa sehingga fokus dan lokus untuk memajukan suatu desa lebih terarah dan terpusat. Selain itu, alasan lain dari perumusan IDM adalah menghindari moral hazard dalam mencapai sasaran-sasaran pembangunan desa sehingga tidak mengulangi praktek-praktek pembangunan yang serba bias dan merugikan kehidupan desa. Dari ketiga dimensi tersebut, salah satu indeks yang harus dipenuhi oleh suatu desa adalah Indeks Ketahanan Lingkungan (IKL) (Kementerian Desa, Pembangunan Daerah Tertinggal dan Transmigrasi, 2019). Indeks ini erat kaitannya dengan kualitas kehidupan lingkungan dalam arti yang menyeluruh dan tidak terbatas hanya pada persoalan lingkungan rumah masyarakat desa saja.

Dalam konteks desa maka lingkungan dapat diartikan sebagai keseluruhan kondisi ekologi yang berada pada desa tersebut meliputi kehidupan manusia, kualitas tanah, kualitas air, dan kualitas udara dan termasuk kualitas keberadaan hayati yang berfungsi sebagai penopang kehidupan masyarakat desa. Tabel I menunjukkan komponen dari penyusun indeks ketahanan lingkungan.

Tabel I. Dimensi dan Indikator dalam Indeks Ketahanan Lingkungan

\begin{tabular}{ll}
\hline \multicolumn{1}{c}{ Dimensi } & \multicolumn{1}{c}{ Indikator } \\
\hline Kualitas & $\begin{array}{c}\text { 1. Ada atau tidak adanya pencemaran air, } \\
\text { tangkungan dan udara; dan } \\
\text { 2. Terdapat sungai yang terkena limbah. }\end{array}$ \\
Potensi & $\begin{array}{c}\text { 1. Kejadian bencana alam (banjir, tanah } \\
\text { Rawa }\end{array}$ \\
longsor, kebakaran hutan); dan \\
dan & $\begin{array}{c}\text { 2. Upaya atau tindakan terhadap potensi } \\
\text { bencana alam (tanggap bencana, jalur }\end{array}$ \\
Tanggap & evakuasi, peringatan dini dan ketersediaan \\
Bencana & peralatan penanganan bencana). \\
Sumber:Peraturan Menteri Desa, Pembangunan Daerah Tertinggal, dan \\
Transmigrasi Republik Indonesia Nomor 2 Tahun 2016
\end{tabular}

Adapun tujuan dari penyusunan indeks ini adalah untuk mendukung upaya pemerintah terutama pemrintag desa dalam mengatasi pengentasan desa tertinggal dan peningkatan desa mandiri. Sementara itu secara lebih spesifik terdapat amanat dari indeks ini yang sejalan dengan tujuan dari EBP yaitu Untuk menjamin penyediaan data dan informasi yang akurat, tepat dan akuntabel, perlu dilakukan pengelolaan Indeks Desa Membangun; Indeks Desa Membangun dikelola oleh Direktorat Jenderal Pembangunan dan Pemberdayaan Masyarakat Desa melalui Direktorat Pelayanan Sosial Dasar pada Kementerian Desa, Pembangunan Daerah Tertinggal dan Transmigrasi; Pendayagunaan Indeks Desa Membangun lebih lanjut dapat dilakukan dengan:

1. Memperkuat hasil analisis pembangunan dan pemberdayaan masyarakat Desa denganjenis indeks yang lainnya, seperti indeks keadilan gender, indeks demokrasi, indeks kapasitas dan tata kelola pemerintahan yang secara tegas dengan lokus Desa;

2. Penentuan peringkat Desa dalam keberhasilan pembangunan dan pemberdayaan masyarakat Desa;

3. Bahan advokasi di tingkat Pemerintah Pusat, Provinsi, Kabupaten/Kota maupun Desa dalam mendorong keberpihakan kebijakan dan anggaran yang dapat meningkatkan kemandirian Desa;

4. Digunakan sebagai alat evaluasi terhadap proses 
perencanaan dan pelaksanaan pembangunan Desa;

5. Merumuskan fokus dan lokus pembangunan desa dengan pendekatan dan pemenuhan kebutuhan pembangunan Desa bersifat spesifik sesuai dengan indikator yang ada dalam Indeks Desa Membangun (Kementerian Desa, Pembangunan Daerah Tertinggal dan Transmigrasi, 2019).

\section{Materi Sosialisasi: Kebijakan berbasis bukti}

Kebijakan publik sangat penting bagi organisasi pemerintahan karena ia berhubungan dengan hajat hidup masyarakat yang merupakan kelompok sasaran dari berbagai kebijakan. Oleh karena itu, kebijakan publik yang dirumuskan harus menggambarkan secara obyektif masalah yang dihadapi agar intervensi yang dilakukan tidak melenceng dari masalah itu sendiri. Selain itu EBP juga penting untuk merumuskan desain kebijakan agar sesuai dengan karakteristik masalah dan keinginan masyarakat sebagai sasaran dari kebijakan publik. Bukti dalam dunia akademis adalah lambang dari imparsialitas yang merupakan syarat dalam menghasilkan produk yang berkualitas, kebijakan sebagai salah satunya (Pawson, 2002b; Young et al., 2002). Pengertian lain dari bukti adalah pendekatan model rasional yang dimaksudkan untuk memecahkan masalah dengan berfokus pada penggalian penyebab masalah dan pengetahuan ilmiah tentang hubungan sebab akibat yang terjadi dalam masalah.

Dalam perjalanannya untuk menjadi bahan pembuatan kebijakan, bukti yang tersedia harus diterjemahkan menjadi bahasa-bahasa kebijakan. Terdapat beberapa alternatif langkah untuk melaksanakan hal tersebut. Pertaa adalah dengan mengidentifikasi kebutuhan pemerintah dalam hal ini adalah pemerintah desa terutama untuk mengetahui kapasitas pemanfaatan produk penelitian untuk kebijakan publik. Kedua adalah dengan merumuskan rancangan dan melakukan penelitian dengan strategi yang tepat sesuai dengan kebutuhan dari pemerintah dan masyarakat desa. Terakhir adalah dengan melakukan penyebaran informasi hasil riset yang bermanfaat bagi para pemangku kepntingan (Head, 2010; Young et al., 2002).

Beberapa manfaat dari adanya pengintegrasian bukti obyektif ke dalam kebijakan antara lain: Pertama adalah membantu pemerintah desa dalam mengidentifikasi masalah publik dan penyebab utama dari masalahmasalah publik tersebut. Selanjutnya, EBP dapat pula membantu pemangku kepentingan untuk mendesain kebijakan dan alternatif-alternatifnya berdasarkan kapasitas organisasi pelaksana kebijakan. Manfaat lainnya adalah untuk menyusun serangkaian instrument untuk menyelidiki dampak dan merupakan input dari program kedepannya. Keempat adalah untuk memantau pelaksanaan program dan kebijakan, mengukur biaya, manfaat dan kinerja kebijakan serta kepekaan kebijakan untuk diterapkan dalam situasi yang berbeda. Terakhir adalah, dalam jangka panjang dapat digunakan untuk menilai biaya dan kinerja yang dihasilkan oleh program-program yang berbasis bukti (Asmara \& Handoyo, 2015).

Berkaitan dengan pemanfaatan bukti untuk pembuatan kebijakan, kami mengidentifikasi beberapa alternatif bukti yang dapat dijadikan sebagai bahan pembuatan kebijakan yang dapat mengarahkan desain serta alokasi sumber daya baik manusia teknologi maupun anggaran. Tabel II berisi berbagai macam produk yang dapat dimanfaatkan untuk urusan ini dan tentunya masih dapat dikembangkan lagi sesuai dengan kebutuhan pemerintah desa. Selain itu, pemerintah desa juga dapat mengembangkan instrument sendiri yang berlandaskan pada kebutuhannya.

Secara umum, bukti-bulti ilmiah dapat diakses oleh Pemerintah Desa Lorok dari BPS Kabupaten Ogan Ilir, selain itu beberapa data dari Pemerintah Kabupaten Ogan Mir juga dapat diakses untuk menjadi bukti. 
Beberapa kementerian juga bahkan memiliki data yang basisnya adalah desa. Ini juga dapat mereka manfaatkan untuk menjadi landasan dalam membuat kebijakan agar lebih tepat sasaran.

Tabel II. Bukti yang dapat dimanfaatkan untuk pembangunan Desa Lorok

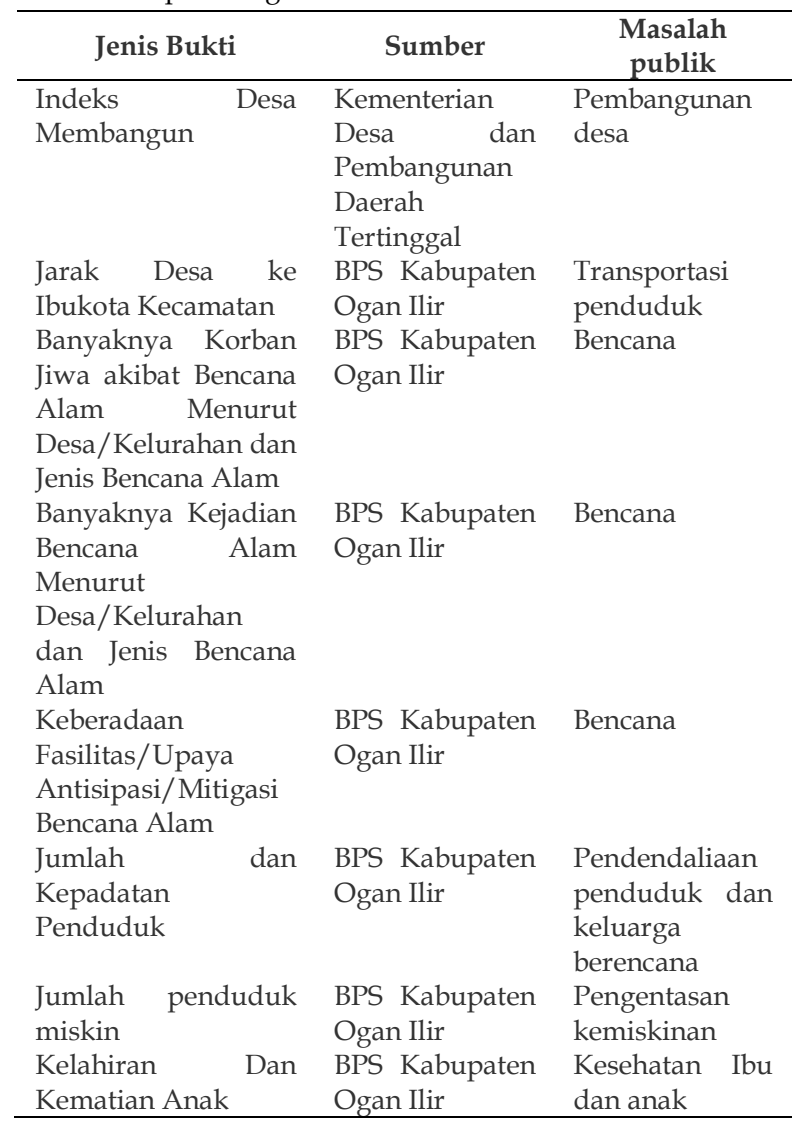

\section{Kebijakan berbasis Bukti Desa Lorok}

Sebelum jauh berbicara mengenai arah pembangunan ketahanan lingkungan di Desa Lorok, kami tersebih dahulu melakukan focus group discussion yang berisi tentang bagaimana meanfaatkan data untuk kebijakan. Kami mengajak para pemangku kepentingan di Desa Lorok untuk bersama-sama membuat bagan tentang bagaimana aktivitas ini dimulai dan berkontribusi pada pembuatan kebijakan dan program yang lebih tepat sasaran.

Gambar 1 berisi alur pembuatan kebijakan berbasis bukti sebagai hasil dari FGD antara tim pengabdian masyarakat dengan pemangku kepentingan di Desa Lorok. Secara umum, terdapat delapan tahapan yang harus dilalui untuk mencipatakn kebijakan berbasis bukti. Langkah ini dimulai dengan melakukan inisiasi kebijakan atau program. Inisiasi program mewajibkan adanya evaluasi dan peninjauan dari program sebelumnya dan program lain yang sama namun diterapkan di daerah lain untuk belajar kekurangan dan kesuksesan dari program tersebut.

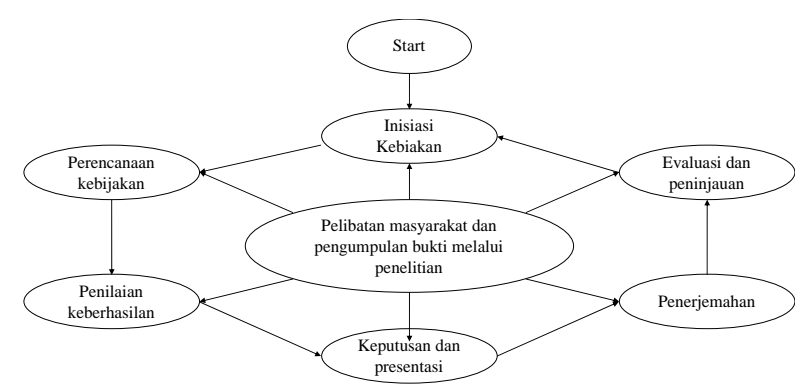

Gambar 1. Alur pembuatan kebijakan berbasis bukti

Inisiasi kebijakan juga mengharuskan adanya pelibatan masyarakat yang salah satunya dapat dilakukan dengan mengumpulkan bukti melalui penelitian. Masyarakat juga dapat memberikan umpan balik terhadapkebijakan yang diinisiasi. Keduanya menghasilkan perencanaan kebijakan. Sumbangsih penelitian dan masyarakat juga dapat dilakukan untuk bersama-sama menyusun kriteria evaluasi kebijakan. Kriteria ini bersama sama dengan perencanaan kebijakan kemudian dibuat menjadi suatu kebijakan. Masyarakat juga dapat menyampaikan usualnnya terkait dengan proses ini. Kebijakan tersebut tentunya harus diseminasikan untuk mendapatkan pengakuan dari masyarakat.

Setelah kebijakan diimplementasikan, kebijakan kemudian dilakukan upaya untuk menerjemahkan hasilnya berdasarkan pada kriteria yang disusun pada saat proses penilaian keberhasilan kebijakan. Hasil ini kemudian amsuk dalam proses evaluasi dan peninjauan yang juga melibatkan masyarakat dan penelitian. Ini kemudian kembali ke fase awal yaitu inisiasi kebijakan. hasil dari evaluasi dan peninjauan akan menjadi landasan dalam kebijakan selanjutnya. 


\section{Studi Kasus: Indeks Ketahanan Lingkungan Desa Lorok}

Sebagaimana indeks ketahanan lingkungan merupakan bagian dari Indeks Desa Membangun (IDM). Secara umum, Tabel III berisi data IDM dari tahun 2019-2020. Dalam dua tahun terakhir, Desa Lorok berstatus sebagai desa berkembang. Jika dilihat lebih detail, ia bergerak turun dari 0,6552 di tahun 2019 menjadi 0,6232 di tahun 2020, turun $5,13 \%$.

Tabel III. Bukti yang dapat dimanfaatkan untuk pembangunan Desa Lorok

\begin{tabular}{cccl}
\hline Status IDM & Tahun & Skor & $\begin{array}{c}\text { Peningkatan (+)/ } \\
\text { Penurunan (-) }\end{array}$ \\
\hline Desa Berkembang & 2019 & 0,6552 & - \\
Desa Berkembang & 2020 & 0,6232 & $-5.13 \%$ \\
\hline
\end{tabular}

Sumber: Kementerian Desa, Pembangunan Daerah Tertinggal dan Transmigrasi, 2020

Berasarkan hasil studi dengan mempertimbangkan nilai IDM, termasuk di dalamnya adalah Indeks Ketahanan Lingkungan. Beberapa rekomendasi yang dapat diberikan adalah sebagaimana terdapat dalam Tabel IV. Secara umum, rekomendasi kebijakan dibuat berdasarkan dimensi dan indikator penilaian dalam Indeks Ketahanan Lingkungan yang langsung menyasar pada pokok permasalahan dan rekomendasi dibuat untuk memecahkan masalah.

Dimensi kualitas lingkungan hidup, kami merekomendasikan Desa Lorok untuk mengurangi Pengurangan pencemaran air di Desa, pencemaran tanah di Desa, pencemaran udara di Desa, sungai yang terkena pembuangan limbah. Sebagai contoh, masyaralat dapat melakukan gerakan 3R yaitu reduce, reuse, dan recyle. Kemudian untuk dimensi kedua yaitu Potensi Rawan Bencana dan Tanggap Bencana, rekomendasinya adalah untu membangun masyarakat tangguh bencana dan membuat Fasilitas Mitigasi Bencana Alam di Desa Berupa Peringatan Dini Bencana, Fasilitas Mitigasi Bencana Alam di Desa Berupa Perlengkapan Keselamatan, dan Fasilitas Mitigasi Bencana Alam di Desa Berupa Jalur Evakuasi.
Tabel IV. Rekomendasi kebijakan pembangunan ketahanan lingkungan

\begin{tabular}{|c|c|}
\hline Dimensi / Indikator & Rekomendasi \\
\hline $\begin{array}{l}\text { Kualitas lingkungan } \\
\text { 1. Ada atau tidak adanya } \\
\text { pencemaran air, tanah } \\
\text { dan udara; dan } \\
\text { 2. Terdapat sungai yang } \\
\text { terkena limbah. }\end{array}$ & $\begin{array}{l}\text { Pengurangan pencemaran air } \\
\text { di Desa, pencemaran tanah di } \\
\text { Desa, pencemaran udara di } \\
\text { Desa, sungai yang terkena } \\
\text { pembuangan limbah }\end{array}$ \\
\hline $\begin{array}{l}\text { Potensi Rawan Bencana dan } \\
\text { Tanggap Bencana }\end{array}$ & $\begin{array}{l}\text { 1. Pembangunan masyarakat } \\
\text { tangguh bencana }\end{array}$ \\
\hline $\begin{array}{l}\text { 1. Kejadian bencana alam } \\
\text { (banjir, tanah longsor, } \\
\text { kebakaran hutan); dan } \\
\text { 2. Upaya atau tindakan } \\
\text { terhadap potensi } \\
\text { bencana alam (tanggap } \\
\text { bencana, jalur evakuasi, } \\
\text { peringatan dini dan } \\
\text { ketersediaan peralatan } \\
\text { penanganan bencana). }\end{array}$ & $\begin{array}{l}\text { 2. Pembuatan Fasilitas } \\
\text { Mitigasi Bencana Alam di } \\
\text { Desa Berupa Peringatan } \\
\text { Dini Bencana, Fasilitas } \\
\text { Mitigasi Bencana Alam di } \\
\text { Desa Berupa Perlengkapan } \\
\text { Keselamatan, dan Fasilitas } \\
\text { Mitigasi Bencana Alam di } \\
\text { Desa Berupa Jalur } \\
\text { Evakuasi }\end{array}$ \\
\hline
\end{tabular}

\section{KESIMPULAN}

Kegiatan pengabdian masyarakat ini bertujuan untuk meningkatkan pemahaman masyarakat dan pemangku kepentingan dalam pembuatan kebijakan berbasis bukti, dengan mengambil studi kasus pada Indeks Ketahanan Lingkungan sebagai bahan dari EBP. Dalam kegiatan pengabdian masyarakat ini kami memperkerjakan metode sosialisasi dan FGD. Sosisalisasi dimaksudkan untuk menjelaskan EBP dan Indeks Ketahanan Lingkungan sementara dalam FGD kami bersama-sama menyusun langkah-langkah pengintegrasian bukti dalam pembuatan kebijakan dan pencarian rekomendasi kebijakan dalam kasusu indeks ketahanan lingkungan. Hasil dari pengabdian masyarakat ini adalah berupa model pelaksanaan EBP yang sesuai dengan kebutuhan dan karakteristik masyarakat karena ia dirumuskan bersama-sama antara kami sebagai akademisi dan masyarakat. Hasil lainnya adalah rekomendasi kebijakan untuk peningkatan ketahanan lingkungan dengan berfokus pada kriteria penyusun indeks. Beberapa hal yang kami rekomendasikan berkaitan dengan hal ini antara lain:Pembangunan masyarakat tangguh bencana, dan Pembuatan Fasilitas Mitigasi Bencana Alam di Desa Berupa Peringatan Dini 
Bencana, Fasilitas Mitigasi Bencana Alam di Desa Berupa

Perlengkapan Keselamatan, dan Fasilitas Mitigasi

Bencana Alam di Desa Berupa Jalur Evakuasi.

\section{UCAPAN TERIMA KASIH}

Penulis mengucapkan terima kasih kepada LPPM Universitas Sriwijaya yang telah memberi dukungan finansial terhadap pengabdian ini.

\section{REFERENSI}

Agustina, S., Yusuf, S., Fajarica, S.D. 2018. Penyuluhan Peningkatan Kapasitas Unsur Pimpinan Desa Dalam Pengelolaan Pemerintahan Desa Di Desa Lorok Kabupaten Ogan Ilir. Jurnal Pengabdian Sriwijaya. 6(3):644-652. https://doi.org/10.37061/jps.v6i3.7014

Asmara, A.Y., Handoyo, S. 2015. Pembuatan Kebijakan Berbasis Bukti: Studi Pada Proses Pembuatan Kebijakan Standardisasi Alat dan Mesin Pertanian di Indonesia. STI Policy and Management Journal. 13(1):38-57. http://dx.doi.org/10.14203/STIPM.2015.38

Astuti, E., Murwani, J., Sugiharto. 2020. Pelatihan Akuntansi Pemerintahan dan Pengelolaan Dana Desa Pada MGMP Kabupaten Madiun. Dinamisia: Jurnal Pengabdian Kepada Masyarakat. 4(2):214-221. https://doi.org/10.31849/dinamisia.v4i2.359 3

Craft, J., Howlett, M. 2012. Policy formulation, governance shifts and policy influence: location and content in policy advisory systems. Journal of Public Policy. 32(2):79-98. https://doi.org/10.1017/S0143814X12000049

Damayanti, R.A., Syarifuddin, S. 2020. The inclusiveness of community participation in village development planning in Indonesia. Development in Practice. 30(5):624-634. https://doi.org/10.1080/09614524.2020.17521 51

Febrian, R.A., Handrisal, H. 2018. Akuntabilitas Pencapaian Visi, Misi, Dan Program Kepala Daerah Dan Wakil Kepala Daerah Terpilih (Studi Bidang Kehutanan Pada RPJMD 2014-
2019 Provinsi Riau). Kemudi: Jurnal Imu Pemerintahan. 3(1):1-35.

Gallego, I., Font, X. 2020. Changes in air passenger demand as a result of the COVID-19 crisis: using Big Data to inform tourism policy. Journal of Sustainable Tourism. 29(9):1470-1489. https://doi.org/10.1080/09669582.2020.17734 76

Head, B.W. 2010. Evidence-based policy: Principles and requirements. In Strengthening evidence-based policy in the Australian Federation. 1(2):13-26. Melbourne: Productivity Commission.

Head, B.W. 2008. Three Lenses of Evidence-Based Policy. Australian Journal of Public Administration. 67(1):1-11. https://doi.org/10.1111/j.14678500.2007.00564.x

Kementerian Desa, Pembangunan Daerah Tertinggal dan Transmigrasi. 2020. Peringkat Status Indeks Desa Membangun (IDM): Provinsi Kabupaten Kecamatan. Jakarta: Kementerian Desa, Pembangunan Daerah Tertinggal dan Transmigrasi

Kementerian Desa, Pembangunan Daerah Tertinggal dan Transmigrasi. 2019. Status Indeks Desa Membangun (IDM): Provinsi Kabupaten Kecamatan Tahun 2019. Jakarta: Kementerian Desa, Pembangunan Daerah Tertinggal dan Transmigrasi

Kusnanto, H. 2008. Kebijakan Kesehatan Masyarakat Berbasis Bukti. Jurnal Manajemen Pelayanan Kesehatan. 11(1):2-4

Mustain, L.H.B., Djaja, K. 2017. The burden of regional development planning in indonesia: A case study of discrepancies between land use and spatial planning document in banten province. WIT Transactions on Ecology and The Environment. 226(1):253-261. http://doi.org/10.2495/SDP170221

Pawson, R. 2002a. Evidence-based Policy: In Search of a Method. Evaluation. 8(2):157-181. https://doi.org/10.1177/13589020020080025 12

Pawson, R. 2002b. Evidence-based Policy: The Promise of 'Realist Synthesis'. Evaluation. 8(3):340-358. https://doi.org/10.1177/13563890240146244 8 
Purwaningrum, F., Short, S.D. 2018. Epistemic layers in development planning: A case study of the health sector in the Gunungkidul District, Indonesia. International Journal of Health Planning and Management. 33(4):1200-1210. https://doi.org/10.1002/hpm.2607

Syawie, M., Sumarno, S. 2015. Kebijakan Berbasis Ilmu Pengetahuan. Sosio Informa. 1(1):79-90. https://doi.org/10.33007/inf.v1i1.92

Young, K., Ashby, D., Boaz, A., Grayson, L. 2002. Social Science and the Evidence-based Policy Movement. Social Policy and Society. 1(3):215224.

http://doi.org/10.1017/s1474746402003068 